\title{
SENSE AND SENSIBILITY REVISITED: EMMA TENNANT'S ELINOR AND MARIANNE
}

\author{
CARMEN LARA RALLO \\ Universidad de Málaga
}

\begin{abstract}
Elinor and Marianne is a playfully parodic sequel to Sense and Sensibility in which Emma Tennant explores the lives of Austen's characters after the 'happy ending' of Sense and Sensibility. Apart from exposing the artificiality of some realistic conventions underlying Austen's novel, Elinor and Marianne articulates a change in the narrative mode which replaces the monological perspective of the omniscient narrative by the dialogic focalisation of the multiple narrators of an epistolary novel. This change opens the way for the exploration of the characters of Sense and Sensibility, whose behaviour and attitudes in Elinor and Marianne invite the reader to revisit their presentation and appraisal in Austen's novel.
\end{abstract}

\section{RESUMEN}

Elinor and Marianne es una continuación de Sense and Sensibility basada en juegos paródicos en la que Emma Tennant explora la vida de los personajes de Austen tras el 'final feliz' de Sense and Sensibility. Además de dejar al descubierto la artificialidad de algunas convenciones realistas que subyacen tras la novela de Austen, Elinor and Marianne articula un cambio en el modo narrativo que reemplaza la perspectiva monológica de la narración omnisciente por la focalización dialógica de los narradores múltiples de una novela epistolar. Este cambio hace posible una exploración de los personajes de Sense and Sensibility, cuyo comportamiento y actitud en Elinor and Marianne invitan al lector a volver a considerar la presentación y valoración que de ellos se hacía en la novela de Austen.

Elinor and Marianne (1996) is a playful "Sequel to Sense and Sensibility" in which Emma Tennant, author of other novels like Pemberley and An Unequal Marriage (which are sequels to Pride and Prejudice), offers a humorous insight into the lives of Austen's characters after the ending of Sense and Sensibility. Exposing some of the most characteristic conventions and assumptions of realistic fiction in a narrative that echoes Austen's style 
but which at the same time shifts from the omniscient narrator to the epistolary form, Elinor and Marianne revisits Sense and Sensibility by creating an interesting contrast to the 'happy ending' of Austen's novel.

In this sense, Elinor and Marianne should be contextualised in terms of the cultural phenomenon of 'Austenmania', a twentieth-century trend which has placed Jane Austen as a cultural icon, and which has witnessed an impressive proliferation of sequels to Austen's novels as well as of fiction about Austen herself. Indeed, over sixty continuations of her work were published in the $20^{\text {th }}$ century, especially in the $1990 \mathrm{~s}$, including six sequels to Sense and Sensibility, among which we can mention Joan Aiken's Eliza's Daughter (1994) and Julia Barrett's The Third Sister (1996). Within the context of 'Austenmania', Tennant's sequels have usually been greeted among literary critics with scepticism and contempt. Thus, while Judy Simons suggests that modern sequels such as Tennant's, which "almost invariably focus on marital disharmony and sexual disjunction", "tend to be singularly unsuccessful" (1998: 35-36), Rolf Breuer describes Elinor and Marianne in the following terms: "The silliness of the plot has its counterpart in the insignificance of the style [...] Sometimes Austen's sequel is so absurd that one is unable to suspend disbelief'. One of the goals of the present paper is to counterbalance such negative criticism by showing the relevance of Elinor and Marianne in the context of postmodern feminist fiction, as Tennant's novel revisits Sense and Sensibility by resorting to several postmodern strategies which expose the realistic conventions underlying Austen's text, and which invite the reader to question their response to the characters and ideology of Sense and Sensibility.

Indeed, beyond its place within the context of the current vogue for Austen's work, Elinor and Marianne has to be contextualised in the broad corpus of postmodern feminist revisions. This is so because Tennant's novel exemplifies the postmodern tendency to revisit both popular and canonical texts with the aim of exposing the ideology informing these works, or of giving a voice to previously marginalised characters. Thus, while Angela Carter rewrote popular tales in The Bloody Chamber (1979) in order to expose the ideology of these everlasting stories, authors like Jean Rhys (Wide Sargasso Sea, 1966) have, since the mid-twentieth century, revised canonical works to focus on silenced characters. Within this tendency, feminist writers have embarked on the project of rewriting earlier works on the basis of the idea that "to be a woman is to be an outsider" (Greene, 1991: 17), and that therefore the voice of female characters has traditionally been stifled by the dominant patriarchal ideology. In this context of postmodern feminist revision, Elinor and Marianne occupies a significant position since, in its revisitation of Sense and Sensibility, not only does it allow Austen's characters to speak for themselves, but also gives a voice to the previously silenced Marianne, a voice which exposes the ideology that lies behind Austen's novel.

In the process of postmodern revision, Tennant's work makes use of different postmodern strategies, such as metafiction, parody, intertextuality, and dialogismpolyphony. While metafiction emerges in the form of a challenge to the realistic conventions underlying Austen's novel (artificial closure, poetic justice, and coincidence), the other strategies are deeply connected with the change in the mode of narration. In Elinor and Marianne, the shift from the omniscient narrator to the epistolary form entails the acknowledgement of the postmodern notions of relativism and plurality, notions that 
replace the classical dualism based on binary oppositions which in Austen's work was resolved by the dominion of 'sense' over 'sensibility'; above all, the epistolary form of Tennant's novel offers a new insight into the characters of Sense and Sensibility. In this context, in order to counterbalance the negative reviews on Tennant's sequel, the present paper will try to demonstrate the importance of Elinor and Marianne in the postmodern feminist frame by exploring the way in which Sense and Sensibility is revisited in Tennant's work. Thus, apart from analysing the challenges posed by Elinor and Marianne to the realistic conventions underlying Austen's novel, this paper will concentrate on the insight it offers into the characters of Sense and Sensibility and on the process whereby Austen's ideology is exposed by giving a voice to the previously silenced Marianne.

In the conclusion of Sense and Sensibility, Austen devoted a single chapter to the arrangement of Elinor's and Marianne's marriages, the 'punishment' of Willoughby and the prospect of Margaret's happiness. This quick ending, whose artificiality has been pointed out by critics such as Marvin Mudrick ("We may be assured that everyone turns out to be prudently happy... But we are not to be reconciled"; 1976: 115), is exposed in Tennant's work by means of a dual strategy. On the one hand, her novel as a whole ironically questions what is beyond those 'happy marriages', paying special attention to the relationship between Marianne and Colonel Brandon; on the other hand, by providing a similarly quick and artificial ending to her own novel, Tennant lays bare the conventionality of the conclusion of Sense and Sensibility $(S S)$. The challenge to realistic closures issued by Tennant's novel has two main implications. Firstly, it makes the reader aware of the fact that Austen's ending can been seen as arranged in such a way as to fit into what Gayle Greene (1991: 12) perceives as the only conclusion allowed to women in traditional fiction: that of marriage. Secondly, considering that Patricia Waugh has described metafiction as the self-conscious fiction that "draws attention to its status as an artefact" (1984: 2), Elinor and Marianne (EM) can be assessed as a metafictional novel in the sense that it calls the reader's attention to the analysis of the conventionality and artificiality of realistic closures.

Closure is not the only practice of realistic fiction exposed in Tennant's novel, but another commonplace which EM aims at undermining is that of 'poetic justice', a convention working on different levels of SS. The effects of this convention on Austen's work can be seen not only at the end of the novel, where the 'good' characters are rewarded and the 'bad' ones are punished, but also in the 'punishment' of Marianne's sensibility. Sensibility, which was conceived by Austen in the negative terms of individualism and the worship of self(Butler, 1987: 194), is eradicated from SS through the illness that makes Marianne be re-born to a new 'sensible' self, a self that many critics have seen as an automaton or a being completely alien to the true Marianne.

Again, as in her questioning of closure, Tennant uses a dual strategy to expose the artificiality of 'poetic justice': firstly, by offering an insight into the aftermath of Austen's rewards, that is, by exploring the 'happiness' of the protagonists' marriages; secondly, by setting herself up as a kind of 'poetic justice' who rewards and punishes characters that were left untouched in $S S$ despite their actions and attitudes. In this sense, she punishes the cruel, posh and queenly behaviour of Mrs Ferrars by making her lose all her wealth and, 
above all, by transforming her into a comic figure through her pretended madness; similarly, Mrs Ferrars's conceited son Robert is humorously punished with the fate of being eaten by savages. At the same time, the candid but good-hearted Nancy is rewarded with the opportunity to marry her beloved Dr Davies.

Together with this exposure of 'poetic justice', Tennant carries out a playful revision of the role of coincidence in $S S$. In order to do so, she develops several coincidences among the characters of $E M$, such as the fact that Dr. Davies -Nancy's husband- is Marianne's doctor, or that Meg Cox -who looks after the Ferrars' Parsonage- is the one who writes to Margaret about a love-spell. In their far-fetched nature, such coincidences parodically echo those existing in $S S$, like the complex family pattern which was developed in order to account for both the circumstances surrounding Edward's engagement to Lucy, and Elinor's acquaintance with this same character. In this sense, Edward was portrayed in Austen's novel as a gentleman who had been educated with the uncle of the Steeles, who at the same time were the Middletons' cousins.

Above all, Tennant's intention in writing EM is parodical, aiming at creating a playfully humorous and entertaining novel whose major interest lies not only in its style, which constantly echoes that of Austen's novel, but mainly in the insight it offers into the characters of SS. Thus, although Linda Hutcheon has defined parody as "repetition with critical distance that allows ironic signalling of difference at the very heart of similarity" (1988: 26), if we consider that the parodic practice retains the notion of "a kind of literary mimicry" (Kiremidjian, quoted in Waugh, 1984: 69), Tennant's novel could be seen as an example of this "perfect postmodern form" (Hutcheon, 1988: 4); indeed, EM develops an openly parodic approach to the style and technique of characterisation displayed by Austen in $S S$.

The insight into the characters of Austen's novel that is offered by Tennant's work is made possible by what probably constitutes the most significant change from $S S$ to $E M$ on the formal level: the shift in the mode of narration. In $S S$ all the action was presented by the omniscient, godlike narrator that followed a single point of view: that of Elinor. As a matter of fact, as several critics have suggested, "the entire action is refracted through Elinor's consciousness" (Butler, 1987: 190) since "Elinor is her author's conscience" (Mudrick, 1976: 109). This point of view, which embodied the ideology of the active, struggling Christian, is replaced in Tennant's novel by a multiplicity of voices. Indeed, the epistolary form of EM implies that the novel presents us with as many narrators and points of view as writers of letters.

In this context, and dealing with the practice of intertextuality inherent in any process of revision, Tennant's work could be seen as a "transfocalising revision" (Genette, 1982: 333 ) of $S S$, in the sense that the 'focus' which filters the action is widened from the single approach of Elinor's point of view to the multi-dimensional perspective of several characters-writers. The process of 'transfocalisation' applied in EM is articulated through the Bakhtinian concepts of dialogism and polyphony, according to which language is not a closed and univocal system, but the merging of varied and opposing voices. Dialogism, which "militates against monadism" (Holquist, 1990: 90), runs against the monological discourse imposed by totalitarian ideologies. Such a discourse, in which "the conflicts of languages and voices is apparently resolved... through their subordination to the dominant 
"voice"" (Waugh, 1984: 6), is the starting point from which Tennant develops a dialogic novel constructed by a conflation of the letters that the characters address to each other.

The change in the narrative mode from $S S$ to $E M$ has two main consequences. Firstly, in Tennant's novel we get the information not in a linear way, as it was the case in $S S$, but fragmentarily, having to order and contrast the details given in the different letters to which we have access. In this context, Tennant challenges the apparent cohesion and linearity of Austen's novel by making readers aware of the existence of gaps in her own narrative. In order to do so, certain letters, such as the one written by Edward Ferrars to Elinor (EM 181-82), contain references to other letters that we, even though 'universal addressees', are not allowed to read. At the same time, the gaps and non-linearity of Tennant's work contribute to expose the way in which Austen's novel presented the events narrated through the voice of the godlike narrator as the Truth, the true (though fictional) record of the experiences undergone by the Dashwood sisters. In $E M$, since the monological voice of the omniscient narrator is replaced by the plurality of voices of the different characterswriters, we are led to acknowledge the postmodern realisation of the fact that the Truth does not exist, as the true record of experiences becomes the merging of dialogic and conflicting versions of a narrative that only can be ascertained once the details given in the different letters to which we have access have been contrasted and ordered. Thus, Tennant's novel supports the postmodern notion of the Truth as a construct under which multiple truths coexist.

Secondly, since the characters of EM 'speak' for themselves, we can discover their depth and the hidden features which exist beyond the surface glimpsed in Austen's omniscient narrative. Furthermore, and in line with the dialogic quality of Tennant's novel, many of the characters' traits are revealed by some contradictions in the different first person accounts. Such contradictions lead us even to question the truthfulness of relevant characters, their presentation in $S S$, and certain explanations given in Austen's novel. In other cases, the behaviour of some characters in EM confirms our view of them in $S S$, as it happens with Charlotte Palmer, John Dashwood and Lucy Ferrars-Steele.

This postmodern plurality implies a challenge to binary oppositions and classical dualism which is already at work in the title of Tennant's novel. From the perspective of literary history and tradition, this title could be interpreted as a return to the original version of $S S$, an epistolary novel dating back to 1795 and entitled precisely "Elinor and Marianne" (Butler, 1987: 182). However, considering the conception of Tennant's novel as a sequel to $S S$ which undertakes a transfocalising revision of Austen's work, the title chosen by Tennant has further implications which concern the challenge to the binary

In this context, by resorting to such an expression as "Elinor and Marianne", Tennant makes use of a strategy which is different from the method that she has previously developed to provide a title for her other sequels to Austen's works. Indeed, while in Pemberley and An Unequal Marriage, which invite the reader to revisit the assumptions underlying Pride and Prejudice, Tennant makes use of expressions that echo several aspects of the relationships of the Bennet sisters in Austen's novel, in EM she retains the structure of the title of $S S$ though replacing the binary opposition of the values of 'sense' and 'sensibility' with the first names of the protagonists. Thus, instead of rejecting the binary structure that 
governs the titles of Pride and Prejudice and Sense and Sensibility, as she has done in her earlier sequels, in EM Tennant adopts precisely this structure to articulate a title which marks the emphasis on the characters as individuals rather than as the embodiment of abstract qualities.

In this way, the title of Tennant's novel already signals the movement away from the didactic contrast of the values of 'sense' and 'sensibility' developed in Austen's work. The contrast format of SS, which was typical of the kind of didactic novel that was fashionable by the end of the $18^{\text {th }}$ century (Butler, 1987: 182), emerges not only in the contrast of the protagonists' beliefs and attitudes, but also in the comparisons established between other characters, significantly pairs of sisters and brothers. Thus, if Elinor and Marianne embody the contrast between sense and sensibility, Nancy and Lucy Steele represent the conflict of the abstract values of candour and duplicity, while the conduct displayed by Edward and Robert Ferrars can be assessed in terms of the comparison of civility with conceit and sycophancy.

At the same time, the title of Tennant's novel points to the importance attached to the characters as individuals that can be observed throughout $E M$, especially with regards to the protagonists. As a matter of fact, in Tennant's novel, the interest in Elinor and Marianne does no longer lie in their embodiment of abstract qualities, but in their personal behaviour as autonomous individuals. This emphasis on their individuality is reflected in the fact that Elinor and Marianne are the only female characters of Tennant's novel that keep their first names in the headings of their letters, instead of losing their identity in the complexity of their husbands' names. Thus, while they are always Elinor Ferrars and Marianne Brandon, other female characters are identified as Mrs Thomas Palmer or Mrs Robert Ferrars.

Elinor and Marianne are precisely two of the characters that undergo a change of appraisal from $S S$ to $E M$, as it happens with their husbands. As the protagonists of Austen's 'happy marriages', Edward Ferrars and Colonel Brandon (and, by contrast with him, Willoughby), and, above all, Elinor and Marianne, provide the most interesting analysis in the context of the postmodern feminist revision undertaken by Tennant's novel.

Edward was presented in $S S$ as a polite, civil and loyal character whose virtues, like those of Elinor's, were the ones of the Christian code of values (Butler, 1987: 186). As a result, the image of Edward that prevailed under the influence of Elinor's 'sensible' filter conveyed a very positive portrait which was questioned only by Marianne on the grounds of Edward's lack of sensibility (SS 15). In Tennant's novel, however, his politeness, civility and gentlemanliness become absolute passivity and dependence on his mother, attitudes reflected in the fact that he only writes two letters, and in neither of them does he attempt to help in Marianne's problem. In general, we tend to agree with Elinor when, in her desperation, she calls him a "spineless creature" (EM 139).

As it happened with Edward, the attitude created by the narrator and Elinor's focalisation towards Colonel Brandon in SS was a very positive one. Characterised as a gentleman, always ready to help, and suffering from his past, the only negative approach to his person came, once more, from Marianne. Due to the prevalence of Elinor's perspective, the view that Marianne offered of Brandon's age was presented in childish, exaggerated and rather comical terms: "Did you not hear him complain of the rheumatism? And is not that the 
commonest infirmity of declining life?" (SS 33); "But he talked of flannel waistcoats... and with me a flannel waistcoat is invariably connected with aches, cramps, rheumatisms, and every species of ailment that can afflict the old and the feeble" (SS 34). Even the doubts that Brandon's attitudes could offer to the eyes of sense, such as his silence about Willoughby's character and about his own dark past, are erased from the rational perspective of Elinor and understood in terms of civility and politeness.

In contrast, in Tennant's novel, both the object of Marianne's criticism (Brandon's age) and what should have remained as the object of Elinor's doubt (his past) constitute the main obstacles to the happiness granted at the end of SS. On the one hand, the difference of age between the Colonel and Marianne not only hinders Brandon's understanding of his wife, but also leads him to treat her patronisingly. On the other, the Colonel's dark past emerges in the form of his obsession with the welfare of Eliza. This character appears in Tennant's novel as Brandon's natural daughter (EM 27, 114), thus solving one of the unclear elements of $S S$ and contradicting the explanation given by the Colonel in Austen's novel (SS 176). Above all, in EM Brandon's 'gentlemanliness' is exposed in the way he leaves Marianne alone without paying attention to her sadness, writing to her only almost a fortnight after his departure.

Contrasted with this traditional husband who sees Marianne as his "treasured Wife" (EM 104) and who, in his patriarchal attitude, is convinced that he is going to have a son, the liberal Willoughby is introduced as an idealist dreaming of a perfect and equalitarian society to be founded in America. In Tennant's novel, the importance of Willoughby does no longer lie in his embodiment of a danger to the 'sensible' marriage of Marianne and Colonel Brandon, but in his status as a rebel fighting from for freedom and equality; above all, considering the feminist intention of the sequel, Willoughby plays a relevant role in $E M$ since he is the only man who respects Marianne as an individual. The rascal and villain of $S S$, who like Marianne embodied selfishness, self-sufficiency and complacency (Butler, 1987: 187), is given a new opportunity by Tennant, and even though he again fails, at least he appears in EM as the only one who listens to Marianne's unheard voice.

Although in $S S$ the narratorial voice assured us that, after the discovery of Lucy and Edward's engagement “... confidence between [Elinor and Marianne] was... restored to its proper state" (SS 228), we see how in EM this "proper state" is questioned by the way in which Elinor continues to be "better at concealing... thoughts and feelings than expressing them" (EM 177-78). This attitude is proved by the fact that Elinor does not trust her secrets to her mother or Marianne, as we are shown by the impersonal and distant quality of her letters. In EM Elinor's is no longer the voice of sense and civility, as it was in Austen's novel, but the voice of tradition, restriction, and as far as Marianne is concerned, of oppression: when Marianne tells her sister about her unhappiness and suffering, Elinor's only answer is to side with Brandon, justifying his behaviour in terms of delicacy (EM 114).

Embodying thus the perspective of convention, Elinor reminds her sister that "the sanctity of the marriage vows cannot be betrayed" (EM 83) and, once Marianne has escaped with Willoughby, that she is "living in sin and in urgent need of rescue" (EM 113). Although Elinor states that she is "so concerned for [Marianne]" (EM 84), her only cold action is to 
hypocritically assert: "Marriage is an act of choice, Marianne. You chose Colonel Brandon... and he you..." (EM 83-84), thus echoing her own conversation with Willoughby in Austen's novel ("You have made your own choice. It was not forced on you"; SS 279). Remembering the way in which the omniscient narrator of SS referred to what Elinor sees as Marianne's "choice", the least thing we can do is, as we did with Edward, to agree with Elinor's own view and consider her "a pompous prig" (EM 84).

In Austen's novel the character that suffered most from the dominance of Elinor's perspective was Marianne, the sensibility-driven being that, as critics such as Tony Tanner (1986: 75, 87-88) and Angela Leighton (1994: $54 \mathrm{ff}$ ) have pointed out, was condemned to silence. Her sensibility was 'punished' to a point that she was made to be re-born after her illness to a new sensible self. In EM, by allowing us to hear Marianne's voice directly, without the interference of Elinor, Tennant wants to suggest the oppression -and the artificial conversion to sense- to which this character was subject in SS. The importance of Marianne's voice, perhaps reinforced on a formal level by the fact that the novel begins and ends with her letters, is reflected in the way readers tend to sympathise with the feelings she displays throughout the novel.

Unlike her eldest sister, Marianne shares her deepest thoughts with Elinor, and it is through this openness that we begin to perceive that the supposedly sense-driven woman of the end of $S S$ retains still some glimpses of sensibility, an attitude clearly reflected in her enthusiastic description of the blooming of new flowers (EM 4). Little by little we begin to realise that, apart from keeping some traits of her former sensibility, Marianne is unhappy in her married life (EM 20), unhappiness that has driven her to the state of nervous breakdown revealed in her third letter: "I dream only of gallows and gibbets..." (EM 26); “... Colonel Brandon may continue till Doomsday, and bring forth a progeny of monsters" (EM 28).

Nevertheless, in her next letter we feel that somehow the sincere and open-minded Marianne, the one that existed before the illness, has been recovered, and for the first time she uses her voice to refer to how she "decided" on Brandon. If Elinor embodies in Tennant's novel the perspective of tradition and oppression, Marianne represents the challenge to the established order and the rebellion against women's submission and subordination. On a personal level, Marianne's challenging and rebellious attitude takes the form of her attempted escape with Willoughby to found a colony in the New World. In more general terms, Marianne gives voice to the grievances against the oppression and injustice to which women were subject; in order to do so, she interrupts the sad description of her personal unhappiness with Brandon to become the spokesperson of women's sufferings, in such a way that the complaining 'I' makes way for a defying 'we': "We are no more than beasts... we are in the world to bear children and tolerate neglect and indiference [...] we cannot but survive or die" (EM 74).

After her rebellion, however, and after the second failure of Willoughby, Marianne is again made to be re-born to an artificial and sensible self. Thus, far from describing herself as "the unluckiest woman alive" (EM 74), this 'new' Marianne acknowledges her 'mistake' and considers herself "the happiest and most fortunate woman on Earth" (EM 183). At first sight, this final change contradicts the feminist quality of Marianne's previous behaviour; however, by setting herself up as a kind of 'poetic justice' that 'punishes' Marianne by 
leading her into the 'proper' course, Tennant aims at exposing the artificiality of Marianne's conversion to sense in SS. In doing so, the author of EM achieves a two-fold goal: on the one hand, she challenges the realistic conventions of poetic justice and closure; on the other, by displaying an artificial dominion of sense that parallels that of Austen's novel, Tennant invites the reader to question the reasons that led Austen to make Marianne be reborn to an artificial and sensible self. Thus, the sudden plot twist whereby Tennant transforms the rebellious Marianne into a conformist woman indirectly hints at the ideology informing Austen's work, since the reader is made to realise that the traditional and conservative perspective which is favoured in SS accounts for Austen's urgent need to place Marianne within the borders of sense.

Like the protagonists of Austen's 'happy marriages', some of the secondary characters of $S S$ also undergo a change of appraisal in EM. This is the case of Mrs Jennings, Mrs Dashwood and Margaret, whose behaviour in Tennant's novel, as it happens with that of the main characters, leads us to question their presentation in $S S$. In contrast, other secondary characters such as Charlotte Palmer, John Dashwood or Lucy Ferrars display an attitude that is consistent with that offered in Austen's work.

Charlotte Palmer, who, as we learn from Mrs Jennings's letter, has a new baby and a new house in London, appeared in $S S$ as a good humoured, almost foolish woman. This view is reinforced in $E M$ in the two letters she writes to her mother, letters that are full of insubstantial references to the weather and, above all, of gossip, which appears in the form of expressions such as "it is no secret" (EM 54), "I was informed" (EM 155), or "I hear" (EM 156). Moreover, her foolishness is stressed by the way in which, as in SS, she laughs at all the "droll" things her husband does, even when he forgets that she has had a baby. In this same line, Tennant's novel emphasises the superficiality that could be glimpsed in SS through Charlotte's careless and shallow references to her children: “... for all this talk of suckling and going such an inordinate length of time with one's brood has begun to bore me terribly" (EM 155).

The voice of John Dashwood in EM confirms his selfishness in $S S$, as he refuses to take care of Mrs Ferrars when she is bankrupt (EM 35). This attitude springs from his tendency, already displayed in Austen's work, to consider that his own 'problems' -in fact mere trifles- are too important as to be able to help anybody. Thus, when Elinor asks for help, his only action takes the form of just a useless prediction: "Your problems, with the aid of Edward's prayer and your own practical nature, will soon be overcome" (EM37). Similarly, his passivity and submission to his wife's manipulative strategies, which in the second chapter of Austen's novel took the form of his acceptance of the view that he did not have to help Mrs Dashwood or her daughters economically, has a parallel episode in $E M$ in John's visit to Combe Magna. Even though he arrives there "as head of the Dashwood family and as saviour of... Marianne" (EM 142), his resolution very soon turns into inactivity and an uncommitted desire "... to hear that Colonel Brandon has taught a lesson to $\mathrm{Mr}$ Willoughby..." (EM 144-45).

This episode is narrated in a letter that displays a style which provides evidence to prove that John Dashwood is a pompous character. Indeed, in his description of the people at Combe Magna, he refers to a musician as "the red-haired minstrel" (EM 142), and to the 
manservant as "a turbaned creature" (EM 143). In parallel, while the style of his letters confirms John's pomposity, his comments stress his materialism and meanness, features that are reflected in his constant references to money as well as in his view of both places and characters in terms of material qualities: "a house still well-appointed (though not as elegantly furnished as Norland Park...)" (EM 142), "the rich Miss Grey" (EM 143) [emphasis added]. Likewise, other traits which were glimpsed in $S S$, such as his self-importance and self-interest, can be clearly seen in the behaviour that he displays in $E M$ when, after having received Elinor's invitation to Delaford, he stresses his hope to stay at the Mansion-house and not in the Parsonage (EM 38). With regards to his wife, Fanny is, like Nancy, one of the characters who do not write any letter in the course of Tennant's novel. Given a similar status to that of Mrs Ferrars, she is treated as a comic figure whose only obsession is to demand the linen, plate and silver that were left to Mrs Dashwood in SS.

In her letters, Lucy Ferrars shows herself as an ill-natured, duplicitous and unscrupulous woman who, following the same line of action as in $S S$, enjoys harming people and creating conflicts among them. Thus, the first letter she writes to Marianne is aimed at telling her that the Colonel has been seen with another woman in London (EM 62), while at the same time she tries to convince Edward that Elinor does not love his mother (EM 125). Similarly, the cruelty she displayed in Austen's novel when she insisted on talking with Elinor about her relationship with Edward is enhanced in $E M$ by the way in which she writes to Elinor to make her aware that she has moved to Barton Cottage, where Lucy can show that Edward's "little ways" are very well known by her (EM 132).

In this context, if Lucy takes advantage of Elinor's absence to get closer to Edward again, she tries to approach Colonel Brandon when it is supposed that he has been left by Marianne (EM 179-80). Both actions signal Lucy's lack of suffering towards her husband's death, a fact that confirms that her marriage in $S S$ was only motivated by economic reasons, thus revealing the hypocrisy of comments such as "I am not one to judge a person by his worldly goods" (EM 61). In general, Tennant's work offers a very negative portrait of this unsympathetic character, whose most remarkable features are her manipulative behaviour and sycophancy, as well as her love for gossip. Her gossipy comments, which allow us to learn about some important events such as Elinor's pregnancy, Robert's expedition to Africa, or the success of the party that Mrs Ferrars organises with the Prince Regent, are introduced by expressions which hypocritically place Lucy as the passive recipient of that information: "I am informed" (EM 61), "I was unable to prevent myself from over-hearing when passing..." (EM 125).

In Tennant's novel, this love for gossip becomes also a trait associated to Mrs Jennings, one of those characters whose presentation in EM differs from that offered in SS. Such a change of presentation conforms the strategy whereby Tennant makes readers question their perception of Austen's characters in SS. Thus, in Austen's work Mrs Jennings was seen, always through the filter of Elinor's eyes, as a a good-hearted, kind and motherly woman, a positive view questioned only by Marianne: "she cannot feel. Her kindness is not sympathy; her good-nature is not tenderness. All that she wants is gossip..." (SS 170). As Mudrick (1976: 100) points out, this is so because, according to Marianne's standards, Mrs Jennings is 'wicked' due to her lack of sensibility. 
Regardless the cause of Marianne's perception, it is the one which is favoured in Tennant's novel, where some of the negative features associated with Mrs Jennings's character are her quick change of opinion and the inconsistencies of her reports. Firstly, her quick change of opinion can be observed both in her tendency to support contradictory perspectives in the course of a single letter (EM 44-45), and in her attitude towards characters like Lucy. Indeed, Mrs Jennings forgets very soon her "honest indignation" (SS 314) against this duplicitous character, who is instead praised as a "splendid young woman" (EM 41). Secondly, some of the inconsistencies associated to Mrs Jennings's reports are a source of humour, as when she states that Robert has "gone to shoot crocodiles in Mesopotamia" (EM 40), but others reveal her unreliability and, above all, her love for gossip. This last trait can be clearly observed in her correspondence with the other gossipy character, Lucy, and in her obsessive attempts to get information from working-class people.

Like Mrs Jennings, Mrs Dashwood and Margaret are two characters whose presentation in $S S$ is questioned by Tennant's novel. On the one hand, Mrs Dashwood shows herself as a careless mother, both in her neglect of Margaret, committing with her the same mistakes that she committed with Marianne, and in the tactless way in which she deals with her second daughter. This becomes evident in the fact that she only writes two letters to Marianne in the course of $E M$, thus making readers question one of the final statements of Austen's novel: "Between Barton and Delaford, there was that constant communication which strong family affection would naturally dictate..." (SS 322). While the first of these letters, which is interrupted twice, contains tactless allusions to painful episodes of Marianne's past (EM 58, 66-67), the second one, though short, clearly shows Mrs Dashwood as a manipulative character whose signature "Mama" (EM 124) is one of her strategies to persuade Marianne to go back to what she perceives as her daughter's 'sensible' life (EM 66). On the other hand, Margaret appears as a senseless girl whose selfishness and lack of prudence place her in a position similar to that of Lydia in Pride and Prejudice. Indeed, in the only letter she writes, Margaret worries solely about clothes, without displaying any concern for her sisters' problems.

Above all, the exploration of Austen's characters from the dialogic perspective of $E M$ provides an interesting revision of $S S$, since the multi-dimensional focalisation of an epistolary novel invites the reader to revisit the characters' presentation and appraisal in Austen's novel. Indeed, apart from allowing Austen's characters to speak for themselves, Tennant's novel gives a voice to Marianne, one of the most disturbing silences in SS. By doing so, EM exposes the ideology that lay behind Austen's novel, the conservative ideology that conceived sensibility in the negative terms of individualism and the worship of the self, and which urged Marianne's artificial conversion to sense in SS. In this context, as this paper has tried to demonstrate, EM occupies a significant position in the postmodern feminist frame because, in its revision of Austen's work, Tennant's sequel both challenges the silences of $S S$ and exposes its traditional ideology by resorting to different postmodern strategies. Thus, even though by the end of $E M$ the characters are restored to a situation very similar to that of the ending of $S S$, throughout Tennant's novel we have been offered a playful insight into what is beyond the 'happy ending' of a realistic novel. 


\section{WORKS CITED}

Austen, J. 1995 (1811). Sense and Sensibility. Harmondsworth: Penguin.

Breuer, R. "Jane Austen etc. An Essay on the Poetics of the Sequel". EESE Resources: Jane Austen. [Jane Austen etc. The Completions, Continuations and Adaptations of Her Novels compiled by Rolf Breuer] (Documento de Internet disponible en http://webdoc.sub.gwdg.de/edoc/ia/eese/breuer/biblio.html).

Butler, M. 1987 (1975). Jane Austen and the War of Ideas. Oxford: Clarendon Press.

Genette, G. 1982. Palimpsestes. Paris: Seuil.

Greene, G. 1991. "Feminist Metafiction as Re-vision”, Introduction to Changing the Story. Feminist Fiction and the Tradition. Bloomington: Indiana UP. 1-27.

Holquist, M. 1990. Dialogism. Bakhtin and his world. London and New York: Routledge.

Hutcheon. L. 1988. A Poetics of Postmodernism. London and New York: Routledge.

Leighton, A. 1994. "Sense and Silences”. Sense and Sensibility and Pride and Prejudice. A Selection of Critical Essays. Ed. R. Clark. London: Macmillan. 53-66.

Mudrick, M. 1976. "Irony and Convention versus Feeling”. Sense and Sensibility, Pride and Prejudice and Mansfield Park. A Selection of Critical Essays. Ed. B. C. Southam. London, Macmillan. 89-116.

Simons, J. 1998. "Classics and Trash: reading Austen in the 1990s". Women's Writing 5, 1:27-42.

TANNER, T. 1986. Jane Austen. London: Macmillan.

Tennant, E. 1996. Elinor and Marianne. A Sequel to Sense and Sensibility. London: Simon Schuster.

Waugh, P. 1984. Metafiction. The Theory and Practice of Self-Conscious Fiction. London: Methuen. 